Дмитрий Дубровский

\title{
АКАДЕМИЧЕСКОЕ СООБЩЕСТВО И "ГУМАНИТАРНАЯ" СУДЕБНАЯ ЭКСПЕРТИЗА ПО ЭКСТРЕМИЗМУ В СОВРЕМЕННОЙ РОССИИ
}

\begin{abstract}
Основным предметом рассмотрения в статье является гуманитарная судебная экспертиза в современной России. Особое внимание уделяется вопросу трансформации этой экспертизы, которая излагается следующим образом. В конце 1990-х- начале 2000-х гг. демократически настроенные ученые построили каркас института «гуманитарной» судебной экспертизы и во многом способствовали определению границ свободы слова, активно сотрудничая в этом с правоохранительными органами. Это связано с представлением этих экспертов об опасности фашизма и о гражданской позиции ученого, призванного защищать завоевания молодой российской демократии. В силу этого обстоятельства демократическая наука выступала на стороне государства в ее спорах с консервативно-националистическими кругами, зачастую сталкиваясь в судах с учеными консервативного толка, которые защищали носителей националистических взглядов. В результате к 2000-м годам сложился институт специальной судебной экспертизы и появились методики исследования, которые основаны на опыте проведения таких экспертиз. Во второй половине 2000-х гг. институт экспертизы перехватывается представителями консервативной науки при активном участии государства. Это совпало с появлением специального анти-экстремистского законодательства, которое стало активно сужать пространство свободы слова. В результате часть академического сообщества не только участвовала в применении антиэкстремистского законодательства, но и активно способствовала его научной легитимации. При этом стороны
\end{abstract}

Дмитрий Викторович Дубровский- к. и.н., стипендиат Фонда Коне, Хельсинкский коллегиум современных гуманитарных исследований; доцент, факультет социальных наук, департамент политики и управления, кафедра публичной политики, Национальный исследовательский университет «Высшая школа экономики», Москва; н.с., Центр независимых социологических исследований, Санкт-Петербург, Россия. Электронная почта: dmitry.dubrovsky@gmail.com 
фактически поменялись местами: если в первый период представители демократической общественности в основном выступали на стороне обвинения, то теперь в новых условиях они выступают на стороне защиты против представителей консервативной науки, которые активно поддерживают позицию государства. Таким образом, речь в статье пойдет о своего рода перехвате государством института специальной судебной экспертизы, поначалу созданного в сотрудничестве между гражданским обществом, академическим сообществом («провинциальной науки») и государством, и передаче его в руки политических оппонентов - «туземной науки».

Ключевые слова: специальная гуманитарная экспертиза, свобода слова, анти-экстремизм, академические права и свободы

DOI: 10.17323/727-0634-2020-18-4-721-736

Бурдье в работе «Поле науки» утверждал, что социология науки возможна лишь при понимании того, что «идеологические стратегии» загримированы под «эпистемологические точки зрения, с помощью которых занимающие определенную позицию стремятся оправдать свою собственную позицию и стратегии» (Бурдье 2005: 56). Особенно заметно такое положение вещей в странах, где идеология практически подменяла социальное и гуманитарное знание и стремилась контролировать естественнонаучное. Официально одобряемая позиция в таком случае выдается за «единственно научную». Убеждения ученых либо «государственно одобряемы», либо-в логике идеократического режима-понимаются как прямой вызов государству.

В постсоветском обществе, пережившем крушение идеократического режима, возник серьезный запрос на «объективное знание», особенно связанное с функционированием общества и его проблемами, и, одновременно, наметился антизападный тренд, связанный с провинциализацией российского гуманитарного знания (Соколов, Титаев 2013). После распада СССР гуманитарное и социальное знание поделилось между лагерями, которые Михаил Соколов и Кирилл Титаев обозначили как «провинциальная наука» и «туземная наука». Первая занимается адаптацией и пересказом мировой науки, не создавая новых теорий и концепций, однако включена в международный обмен и контекст; вторая по разным причинам изолирована от внешних источников информации и сосредоточена на разработке автохтонных, зачастую довольно экзотических и архаичных для внешнего наблюдателя тем. Политической особенностью разделения между «провинциальной» и «туземной» наукой, с точки зрения авторов, является разница «между теми, кто верит, что читать западные книги важнее, чем русские, и теми, кто уверен в обратном, проходит более-менее по линии, отделяющей Болотную площадь от Поклонной горы» (Соколов, Титаев 2013:249-50). Другими словами, российская специфика такого разделения имеет идеологическую природу: 
«туземная» наука подчеркнуто «патриотична», это «государственники», в то время как «провинциальная» космополитична, ориентирована на международный контекст, более либеральна и демократична. Это видно, например, при анализе ситуации с переносом квир-теории и в целом экспертизы в области сексуальности (Kondakov 2016, 2020). Таким образом, сложившееся уже в девяностые годы разделение носило не только характер противостояния условно «национальной» и «международной» науки, но и идеологического конфликта между сторонниками либерально-демократического лагеря и консерваторов-государственников.

В истории становления и развития специальной судебной экспертизы эти лагеря в течение времени поменялись местами. Если в начале становления российской демократии академическое сообщество активно включилось в процесс защиты меньшинств от ксенофобии и дискриминации, в то, что носило название антифашизма (противостояние ксенофобским националистическим проектам и практикам), то консерваторы, как правило, националистически настроенные, активно принимали участие в защите тех, кого привлекали по суду за «разжигание вражды и ненависти». Таким образом, в настоящем тексте я собираюсь, прежде всего, объяснить логику и причины такого развития событий, предложив условное деление этого процесса на два этапа- от начала девяностых годов до появления специального законодательства в 2004 г., и после 2004 г., а также проследить на примерах различных процессов, как идеологическое противостояние между двумя различными лагерями отражается в конкретных судебных процессах этого времени.

\section{Академическое сообщество и правые радикалы (1990-e- 2004 гr.)}

Борьба с проявлениями правого радикализма после распада СССР, прежде всего, стала лозунгом «антифашистской политики» в академических учреждениях, понимаемой и как научный, и как гражданский долг (см., Винников 2011). В то же время активизация запроса на экспертизу в области «межнациональных отношений» привела к активности не только «провинциальных», демократически настроенных ученых, но и тех, кто выступал с консервативных, «патриотических» позиций. Политическая свобода активизировала не только демократический, но и националистический, неожиданно большой для страны «межэтнической дружбы», лагерь, а научные дискуссии по поводу «межэтнических отношений» и эксцессов в этой области происходили и в рамках судебных процессов.

Основной анализ в этой статье проводится на материалах дел, связанных с активизацией русского национализма и антисемитизма. Так, в октябре 1990 г. Константин Смирнов-Осташвили, лидер одного из ответвлений русской националистической организации «Память» осужден за «погром в ЦДЛ» (Центральный дом литераторов) по статье 74 советского 
УК. Обвиняемый на процессе ходатайствовал о привлечении в качестве «специалиста по иудаизму, сионизму, русско-еврейским отношениям» Валерия Емельянова (Дуэль и др. 1993: 159) - одного из авторов в области «научного антисемитизма», арабиста и лидера другого ответвления националистической «Памяти». Суд обошелся без приглашения экспертов в данном вопросе и интерпретировал высказывания самостоятельно с учетом контекста, политической активности обвиняемого и показаний свидетелей (там же: 139-140).

Позже стало очевидным, что именно эта уголовная статья вызывает активизацию академического сообщества, представители которого встают по разные стороны- защиты и обвинения-в ситуации с публикациями заведомо ксенофобского характера. Так, один из активных политических лидеров КПРФ - генерал Альберт Макашов - после ряда выступлений стал объектом внимания правоохранительных органов (Люкайтис 1999) по подозрению в разжигании национальной розни. В результате сотрудниками Института русского языка Юлией Сафоновой и Анатолием Барановым по запросу ФСБ сделана лингвистическая экспертиза высказываний генерала на митинге, при этом основным предметом обсуждения было то, является ли слово «жид» разжигающим национальную вражду и рознь (Баранов и Сафонова 2002). Альтернативная экспертиза, подготовленная по заказу прокуратуры, предлагала видеть в этом слове неожиданный «переход на украинский язык» и в целом считать его синонимом «жадного человека». Таким образом, борьба с тем, что квалифицировалось как «русский фашизм», уже в тот момент предполагала столкновение с его защитниками не только в политическом поле, но и в зале суда.

Помимо лингвистов на обсуждение и решение вопросов «межнациональных отношений» претендовали социологи и этнографы. Так, в Петербурге одним из первых дел, когда знания этнографов и антропологов стали востребованы для решения вопроса о юридической квалификации письменного текста, стало дело националиста и кандидата философских наук Виктора Безверхого в 1994 г. (см., Антифашист 1998). Экспертизу прокуратуры по статье 74 ч.1 проводил один из ведущих российских антропологов Александр Козинцев, который пришел к выводу о том, что публикации, несомненно, разжигают межнациональную рознь и содержат пропаганду расизма и антисемитизма. Тем не менее Прокуратура обратилась в Институт антропологии и этнологии РАН, где в тот момент работал Виктор Козлов, д.и.н., главный научный сотрудник. Вместе с к.п.н. Надеждой Лебедевой они написали другую экспертизу. Следуя плохо скрываемой симпатии к автору и цитируемым им идеологам национал-социализма, Козлов и Лебедева в экспертизе отмечали, что «конечно, Гитлер и Розенберг был страшными злодеями <..> но они не всегда говорили только вредную чушь»,- речь идет, в частности, о гитлеровском наказе «беречь чистоту крови» (Козлов, Лебедева 1994). В результате подсудимый оправдан. 
Показательным было то, что, по сути, речь шла о «битве экспертов», в которой на разных сторонах процесса выступали люди разных представлений о науке и ее авторитетах, соответственно, представители «провинциальной» и «туземной» науки. Появление нового уголовного кодекса в 1996 г., где статью 74 «Нарушение национального и расового равноправия» сменила статья 282 «Возбуждение ненависти и вражды», существенно не изменило общей ситуации в экспертизе. Так, издателю Виктору Корчагину удалось уйти от ответственности за антисемитские публикации, в частности, за перепечатку текста «Катехизис еврея в СССР». Экспертиза, написанная в Российском университете дружбы народов, не нашла в больших выдержках из нацистского манифеста разжигания вражды и ненависти (Дейч 2003:257-258). Не менее скандальным вышло и дело антисемитской газеты «Наше отечество», где по приглашению прокуратуры экспертом выступил доктор наук Юрий Бегунов, который, в частности, утверждал в суде, что «Протоколы сионских мудрецов»- подлинный документ. Дело было закрыто. Примерно в то же время редактор газеты «Правда Тюмени» опубликовал серию статей под общим заголовком «Еврейский заговор», и профессор Тюменского университета Николай Фролов в экспертном заключении четко обозначил свою антисемитскую позицию: «Текст выдержан в духе ненависти, шовинизма, национального превосходства злобной, ростовщической части евреев и полуевреев, иудеев и их сторонников» (Аксельрод 2001). Дело было также закрыто «за отсутствием состава преступления», благодаря позиции ученого-эксперта.

Другим примером прямой защиты погромных текстов экспертами является «социально-политологическая экспертиза» публикаций Виктора Корчагина в журнале «Русич» за 2002 г., выполненная Евгением Степановым и Анатолием Самариным уже в 2003 г., которые в тексте фигурируют как Президент и член секции политических конфликтов соответственно (Степанов, Самарин 2003). В публикации, которая обсуждалась судом, высказывалось мнение, что «христианство - это вероучение для расово неполноценных особей» и что «характерной чертой евреев является корыстолюбие и нравственная неполноценность» (Кобрин 2004). В дальнейшем авторы утверждали, что для них самих ксенофобия является порождением «социального и национального унижения», как следует из текста, русского народа, который «...в результате деятельности сепаратистских национализмов малых народов "расчленил свое национальное тело"» (Степанов, Самарин 2003). Таким образом, националистическая формула «унижения русского народа» использована в данном тексте как научное обоснование расизма и ксенофобии в публикациях защищаемого автора. Корчагин был осужден на год условно (Завтра 2004).

Одним из важных примеров борьбы с антисемитизмом и «битвы экспертов» на этих процессах было дело Константина Душенова. В отношении православного журналиста-юдофоба несколько раз возбуждали уголовные 
дела, но только в 2010 г. он был осужден (Сова 2010), хотя первые попытки возбудить дело относятся к 2004 г. Например, в июне 2006 г. следователь Петербургского управления по особо важным делам отказал в возбуждении уголовного дела по ст. 282 УК РФ в отношении Душенова и его газеты «Русь Православная» на основании экспертизы проведенной д.ф.н. Юрием Бегуновым, д. филос. н., проф. Ольгой Бороздкиной и д. и.н., проф. Анатолием Шмелевым. Эти эксперты уверенно обращаются к делу Манделя Бейлиса как доказанному случаю еврейских жертвоприношений, выражают сомнения в реальности «холокоста» (с маленькой буквы), и в целом утверждают, что «такое многообразие взглядов на мировую и отечественную историю отражает современные демократические ценности плюрализма и свободы информации и является объективной реальностью нашей жизни». Доктор филологических наук Бегунов в тексте приходит к выводу, что «слово "жид" используется в общепринятом в православии смысле как характеристика религиозных экстремистов и фанатиков, сатанистов-христоненавистников, деятельно исповедующих расистские и христоборческие положения Талмуда и Шулхан-Аруха» (Бороздкина и др. 2006). На основании этого заключения следователь вынес постановление об отказе в возбуждении дела. Понадобилось серьезное усилие петербургских экспертов, прежде всего, д.и.н., в.н.с. Института российской истории Российской академии наук (ИРИ РАН) Ирины Левинской и н.с. РГИА д. и.н. Давида Раскина, чтобы дело против Душенова было возбуждено и расследовано. Речь шла уже не о газете «Русь Православная», а о DVD диске с фильмом «Россия с ножом в спине. Еврейский фашизм и геноцид русского народа».

В результате активного противодействия националистов и постоянных отказов в возбуждении дел против откровенных расистов и антисемитов возникает убеждение, что необходимо не только активное участие академических исследователей в производстве экспертизы, но и методическое обоснование такого рода экспертизы. Специалисты МАЭ РАН (СПб) были первыми учеными-гуманитариями, включившимися в расследования и судебные разбирательства по ст. 282 УК РФ. Африканист, этнограф и политик, д.и.н. Николай Гиренко, создавший первую методику проведения такого рода экспертиз, написал введение и раздел по социогуманитарной экспертизе в брошюре «Методика расследования преступлений, совершаемых на почве национальной или расовой вражды или ненависти», изданной Институтом генеральной прокуратуры в СПб в 2002 г. (Винников и др. 2002). Николай Гиренко возглавлял группу по правам национальных меньшинств в МАЭ РАН до своей трагической гибели в 2004г. от рук неонацистов. Выходцы из группы по правам национальных меньшинств Союза ученых после гибели Гиренко продолжили его дело; среди наиболее уважаемых практикующих экспертов сотрудник Музея антропологии и этнографии РАН Валентина Узунова, уже упоминавшаяся сотрудница ИРИ РАН Ирина Левинская и другие. 
Опыт участия в производстве экспертиз в Институте языкознания в Москве еще в начале 1990-х, описанный выше, стал для ряда лингвистов этого института началом большого научно-практического проекта- Гильдии лингвистов-экспертов ГЛЭДИС, созданной и возглавляемой доныне проф. М.В. Горбаневским. ГЛЭДИС в Москве стала пионером производства специальных судебных экспертиз, установив высокие профессиональные стандарты. В дальнейшем в практическое и теоретическое развитие экспертизы внесли свой вклад и другие сотрудники академических учреждений, такие как Юлия Сафонова, Анатолий Баранов, Елена Галяшина, Ирина Левонтина и другие. Уже в начале 2000-х появляются первые публикации лингвистических экспертиз (Горбаневский 2010), а также первые публикации методических рекомендаций по их проведению (Галяшина 2006). В результате активного участия экспертов и развития методики и практики специальной судебной экспертизы, юридические образовательные и исследовательские институты также начинают активно развивать эту часть экспертизы. Так, в Московской государственной юридической академии им. О.Е. Кутафина в 2005 г. появляется кафедра судебных экспертиз под руководством проф. Елены Россинской, где, в частности, работает член ГЛЭДИС Елена Галяшина (Россинская, Галяшина 2017: 53-58). В то же время Юлия Сафонова после активной работы с экспертизами в Институте русского языка им. В. В. Виноградова переходит в Российский Федеральный центр судебной экспертизы и там создает свою методику проведения специальных судебных экспертиз по экстремизму (Секераж, Кузнецов 2016).

Таким образом, появление школы специальной экспертизы в России было результатом именно активного вовлечения Академии в процесс демократического строительства. Эксперты понимали свою работу, прежде всего, как гражданский долг и часть научного процесса, и само вовлечение науки в сферу права было продолжением этого процесса. Важно, что именно социальные науки, как исследовательское поле, стали исходным пунктом для рефлексии ученых о роли гуманитарного и социального знания в процессе трансформации российского общества и об опасностях, подстерегающих ученых на пути его использования для целей правоприменения.

\section{Специальная судебная экспертиза и экспертное сообщество во второй половине 2000-x rr. по настоящее время}

Во второй половине 2000-х гг. два лагеря, «туземная» и «провинциальная» науки, начинают меняться местами, и сегодня консерваторы («туземная наука») в большей, чем раньше, мере определяют, что является экстремизмом, чрезвычайно расширяя это понятие. В то же время ученые демократического лагеря активнее отстаивают свободу слова и активно выступают, в основном, на стороне защиты как религиозных меньшинств, 
так и политических критиков власти, которые зачастую становятся фигурантами дел по экстремизму. Во второй половине 2000-х гг. происходят важные изменения в области борьбы с экстремизмом. Прежде всего, в 2007-2010 гг. государство достигло определенных успехов в борьбе с ультраправым насильственным национализмом (Verkhovsky 2016), и возможно именно поэтому с 2011 г. происходит активный рост дел по статьям об экстремизме, то есть, прежде всего, по 282 статье УК РФ (Судебный департамент 2020).

С этого времени в качестве основных экспертов начинают часто приглашаться не признанные ученые с образованием и опытом, а те, кто готов обеспечить нужный результат безотносительно того, насколько содержание экспертизы выдерживает научную критику. Именно тут проявился политический реванш «туземной» науки. Хороший пример- экспертиза к.ф.н Владимира Рыбникова, доцента Геленджикского филиала Кубанского государственного университета, по лозунгу «Свободу не дают, ее берут», использованному правозащитником Вадимом Карастелевым на митинге Новороссийского комитета по правам человека. В этом тексте автор, ссылаясь на «план Алена Даллеса» заявил, что «госп. Карастылев В.Е., выдвинув лозунг "Свободу не дают, ее берут", <..> служит интересам тех, кто хотел бы расшатать общественно-политический строй современной России» (Рыбников 2009). Важно отметить, что эксперт выступал от имени политологического знания, утверждая очевидную фальшивку (план Даллеса) в качестве принятого судом «обоснования» своего сомнительного вывода.

Представители «туземной» науки используют в своих работах методики, выработанные на первом этапе представителями либерального крыла, при этом зачастую либо фальсифицируя данные, либо применяя их некорректно. Часто объектами экспертиз становятся тексты, принадлежащие политическим оппонентам власти или правозащитникам. Так, например, эксперт из Мурманска к.ф.н. Лариса Горбань в своем исследовании приравняла критику «Единой России» к призывам, направленным против российской государственности, а критику полицейского насилия- к призывам препятствовать законной деятельности правоохранительных органов. В стремлении доказать необходимое филолог использует самые экзотические способы доказательства наличия экстремизма в тексте:

Наличие многократного повтора восклицательного знака на титульной странице (см. «Свободу!!!») - пунктуационного знака, выражающего чувства, экспрессию, призыв, побуждение, свидетельствует о скрытом призыве, побуждении добиться, достичь, получить свободу. <...> [Следовательно,] В текстах и заголовках «Международной правозащитной газеты» скрытые (так!) призывы к насильственному изменению основ конституционного строя и нарушению целостности Российской Федерации заключаются во многократном требовании «свободы» и «прав» (Воронцова 2015). 
Подход «туземной» науки связан с ее ориентацией на защиту государства от «экстремистов», под которыми часто понимаются любые политические оппоненты. Так, появляются экспертные методики, в которых критика властей или партии «Единая Россия» описывается, как пример экстремизма (Зеленина, Суслонов 2009: 48-50). На этом этапе в экспертизе появляются экзотические научные концепции, которые характерны именно для «туземной» науки. В частности, многочисленные рассуждения о «языковом зомбировании» и «языковой манипуляции» чаще всего опираются на непризнанные в мире, но очень популярные в России концепции «психологического манипулирования» и «языкового манипулирования». В иске петербургской прокуратуры о признании экстремистскими проповедей пастора Бранхема сотрудники СПбГУ д.с.н. Елена Островская, к.псих.н. Ирина Кузнецова и историк Илья Ратьковский в документе, названном ими «социолого-религиоведческой реконструкцией» идеологического содержания текстов, утверждали, что «использование аргументов, которые нельзя верифицировать», это пример «языковой манипуляции» (Островская и др. 2019). Интересно, что и в этом деле произошла битва экспертов, поскольку исследование на стороне ответчика, то есть, в защиту права христиан распространять свои проповеди, высказались религиоведы Европейского университета в СПб проф. Сергей Штырков и проф. СПбГУ Александр Панченко ${ }^{1}$ В экспертизе религиовед Штырков обратил внимание на то, что «богословская полемика, в которой дискутирующие стороны обвиняют друг друга в отступлении от истинного учения Иисуса Христа и неверной трактовке Библии, является заурядным аргументом в подобных диалогах между представителями разных конфессий» (Дубровский 2018а). Другими словами, эксперты выступили в защиту религиозной свободы от тех, кто видит в проповедях пастора «языковую манипуляцию», оскорбляющую, по мнению других экспертов, «католическую и другие церкви».

Однако наиболее показательным трендом второго этапа развития специальной судебной экспертизы становится, как уже было сказано, появление постоянного пула представителей «туземной» науки, которые начинают постоянно выступать «от имени российской науки» как специальные судебные эксперты. Не имея релевантных исследований и публикаций, как правило, никак не связанные ни с какими экспертными сообществами, такие эксперты становятся ведущими по экстремистским делам. В СПбГУ ведущего филолога и специалиста по юридической лингвистике Сергея Кузнецова, который делал экспертизы по экстремизму, заменил историк журналистики, преподаватель факультета журналистики проф. Борис Мисонжников, который от имени университета стал выступать основным экспертом по этому вопросу. Так, в деле петербургской наци-

\footnotetext{
${ }^{1}$ Последствием реакции СПбГУ на это исследование, ставящее под сомнение «официальную» экспертизу СПбГУ, было непродление контракта с профессором Панченко.
} 
оналистки Гариной они утверждали, что сотрудники отдела по борьбе с экстремизмом МВД (Центра «Э») являются социальной группой, по отношению к которой подозреваемая разжигала вражду и сеяла рознь (Дубровский 2019). Активное использование термина «социальная рознь» в контексте защиты от нее сотрудников правоохранительных органов, ФСБ, власти в целом очень показательна с точки зрения не только расширительного понимания экстремизма, но и этатистской ориентации экспертов обвинения, представляющих «туземную» науку.

Свои идеологические предпочтения и методологические подходы проф. Борис Мисонжников довольно откровенно изложил в пространном тексте, посвященном своей экспертной работе, где он обвинил «либералов» в том, что они «пиарятся на унавоженной нацистами почве», а потом уточнил:

идеологическая работа < ..> бывает общественно опасной: есть, в частности, понятие суггестии, которая предполагает такую силу внушения, что у индивида, образно выражаясь, крыша поедет и он натворит такое, чему потом сам будет удивляться. Вообще лингвисты и психологи довольно серьезно изучают факторы вербального воздействия на сознание, исследуют даже возможности «дискурсивного оружия». Всё это очень серьезно (Мисонжников 2018).

Повторимся, что перед нами текст доктора филологических наук, профессора, преподавателя СПбГУ, автора многочисленных экспертиз, однако научный уровень текста вызывает многочисленные вопросы (Дубровский 2018b).

Наиболее яркими представителями «туземной» науки, отметившимися на поприще специальной судебной экспертизы, являются Наталья Крюкова, к.пед.н., ведущий эксперт АНО «Центр социокультурных экспертиз» в Москве, и ее многолетний соавтор, доктор культурологии Виталий Батов. Этот тандем является авторами экспертизы по лозунгу на футболке «Убей в себе раба!» (Челищева 2016), где утверждается, что данный слоган- экстремистский, поскольку в нем содержится «призыв к насилию над самим собой», т.е. призыв к самоубийству. Кроме того, Батов объяснял, что лозунг «Убей в себе раба!» «подталкивает людей к мысли о том, что в России [существует] рабство» и призывает «на борьбу с рабством- то есть с государственным строем». Другими словами, перед нами- просто идеологический донос под видом научной экспертизы (Дубровский 2019). В целом предлагаемое в судебных экспертизах «научное» обоснование в большом ряде случаев является просто вольным пересказом идеологии, стоящей за желанием «туземной науки» защитить государство от воображаемой угрозы. В то же самое время, это является примером того, как идеология выдает себя за эпистемологию, когда охранительные тенденции в гуманитарном и социальном знании притворяются научным исследованием для серьезного ограничения гражданских свобод, инициированного государством. 


\section{Заключение}

До 2006 г. производство экспертиз отдавалось, в основном, академическим ученым, связанным с либеральным лагерем, однако теперь экспертиза чаще проводится представляетителями консервативно ориентированной «туземной науки». Трансформация институциальной организации экспертизы ведет, с одной стороны, к падению уровня независимости экспертного знания в суде, и с другой- снижение профессиональности экспертизы. На это указывают и недавние решения Европейского суда по правам человека, в которых рассматриваются, вопросы специальной судебной экспертизы, в частности Dmitriyevskiy vs Russia Application no. 42168/06, Stomakhin vs Russia no. 52273/07, Ibragim Ibragimov and others vs Russia no. 1413/08 and 28621/11. Учитывая возрастающий обвинительный уклон российского правосудия (Кондрашев 2017), возникает широкое поле для расширения неправомерного применения анти-экстремистского законодательства.

В то время как демократическая «провинциальная» наука находится преимущественно на стороне необоснованно обвиняемых, стремится к расширению свободы слова, представители «туземной» науки активно выступают на стороне государства, поддерживая и «научно» обосновывая случаи неправомерного ограничения свободы слова, используя при этом экзотические и ненаучные концепции и теории. Причиной этого обстоятельства является очевидная смена государством парадигмы, консервативный поворот, который обратил экспертизу как инструмент совместной борьбы государства и демократически настроенной академической среды в инструмент ограничения свободы слова и борьбы с экстремизмом, понимаемым зачастую неоправданно широко.

\section{Выражение признательности}

Автор благодарит научную сотрудницу МАЭ РАН В. Г. Узунову и бывшую сотрудницу РФЦСЭ Ю. А. Сафонову за возможность использования материалов их личных архивов.

\section{Материалы для анализа}

Аксельрод А. (2001) Антисемитизм в законе. Вестник КЕРООР «ДА», 5. Доступно по ссылке: http://www.jewukr.org/observer/archives/anti05_r.html (дата обращения: 17 ноября 2020).

Антифашист (1998) Информационно-аналитический бюллетень. Доступно по ссылке: http://aha.ru/ ofa/12-1.htm (дата обращения: 17 ноября 2020).

Баранов А.Н., Сафонова Ю.А. (2002) Заключение экспертов. Митинг 04 октября 1998 г. в Москве на Смоленской-Сенной площади. М. В. Горбаневский (ред.) Цена слова. Из практики лингвистических экспертиз текстов СМИ в судебных процессах по защите чести, достоинства и деловой репутащии 3-е издание, исправленное и дополненное. М.: Галерея: 73-83. 
Бороздкина О. Я., Бегунов Ю.К., Шмелев А.Н. (2006). Заключение экспертов. Русь Православная. Доступно по ссылке: http://web.archive.org/web/20060706183012/http:/ www.rusprav.org/2006/new/60.htm (дата обращения: 17 ноября 2020).

Винников А. Я., Гиренко Н. М., Коршунова О.Н., Серова Е. Б., Узунова В.Г. (2002) Социогуманитарная экспертиза преступлений на почве ненависти. СПб.

Воронцова В. (2015) Приговор из будущего. Новые известия. Доступно по ссылке: https://newizv.ru/news/society/21-01-2015/213447-prigovor-iz-budushego (дата обращения: 17 ноября 2020).

Галяшина Е. И. (2006) Лингвистика VS экстремизма. М.: Юридический мир.

Горбаневский М.В. (ред.) (2010) Цена слова. Из практики лингвистических экспертиз текстов СМИ в судебных процессах по защите чести, достоинства и деловой репутации. М.: Галерея.

Дейч М. (2003) Коричневые. Доступно по ссылке: https://www.e-reading.club/chapter. php/18632/86/Deiich_-_Korichnevye.html (дата обращения: 17 ноября 2020).

Завтра (2004) Корчагина все судят. Доступно по ссылке: https://zavtra.ru/ blogs/2004-05-0561 (дата обращения: 17 ноября 2020).

Зеленина О. В., Суслонов П.Е. (2009) Методика выявления признаков экстремизма. Прочессуальные исследования (экспертизы) аудио-, видео-и печатных материалов. Научно-практическое пособие. Екатеринбург: Уральский юридический институт.

Кобрин К. (2004) Редактору журнала «Русич» вынесен приговор в разжигании межнациональной и религиозной розни. Радио Свобода. Доступно по ссылке: https:/ www.svoboda.org/a/24192357.html (дата обращения: 17 ноября 2020).

Козлов В. И., Лебедева Н.М. (1994) Заключение экспертизы по делу № 211717. Личный архив В.Г. Узуновой.

Левинская И.А. (2007) Социгуманитарная судебная экспертиза. Доступно по ссылке: http://web.archive.org/web/20090106000938/http:/rusprav.org/DeloDushenova/Addendum/ ExpertiseOfProsecution_1.html (дата обращения: 17 ноября 2020).

Люкайтис Д. (1999) Дело погромной важности. Коммерсантъ. Доступно по ссылке: https://www.kommersant.ru/doc/15990 (дата обращения: 17 ноября 2020).

Мисонжников Б. (2018) Точки над і или Эксперт, стряпчий Виталик, и депутат Резник. Петербургский публицист. Доступно по ссылке: https://spbspeaks.ru/2018/02/11/ борис-мисонжников-точки-над-і-или-эк / (дата обращения: 17 ноября 2020).

Островская Е.А., Кузнецова И.В., Ратьковский И. С. (2019) Экспертиза по делу публикации проповедей пастора Уильяма Бранхема. Центр экспертиз СПБГУ. Личный архив автора.

Раскин Д.И. (2007) Заключение эксперта. Доступно по ссылке: http://web.archive.org/ web/20090106000938/http:/rusprav.org/DeloDushenova/Addendum/ExpertiseOfProsecution_1. html (дата обращения: 17 ноября 2020).

Рыбников В. (2009) Независимое экспертное заключение. Газета.ру. Доступно по ссылке: https:/www.gazeta.ru/politics/2009/09/10_a_3258922.shtml?p=incut\&number=2 (дата обращения: 17 ноября 2020). 
Степанов Е. И., Самарин А.Н. (2003) Социально-политологическая экспертиза. М.: Центр конфликтологии ИС РАН. Личный архив автора.

Сова (2010) Вынесен приговор главному редактору «Руси Православной». Доступно по ссылке: https://www.sova-center.ru/religion/news/extremism/counter-extremism/2010/02/ d17914/ (дата обращения: 17 ноября 2020).

Судебный департамент (2020) Данные судебной статистики. Доступно по ссылке: http://www.cdep.ru/index.php?id=79 (дата обращения: 17 ноября 2020).

Челищева В. (2016) «Убей в себе раба»- призыв к насилию. Как судебная экспертиза в России превратилась в фарс. Новая Газета. Доступно по ссылке: https://clck.ru/ RxtKm (дата обращения: 17 ноября 2020).

\section{Список источников}

Бурдье П. (2005) Поле науки. Шматко Н.А. (ред.) Социология под вопросом. Социальныле науки в постструктуралистской перспективе. М.: Праксис: 15-56.

Винников А.Я. (2011) Эволюция антифашистского движения в России: от советского антифашизма к интеллектуальному и гуманитарному антифашизму. Антропологический форум, 14:310-320.

Дубровский Д. (2018а) Специальная экспертиза в ноябре-декабре 2018 г. Amicus Curiae. Доступно по ссылке: https://www.amicus-curiae.info/analytics/674 (дата обращения: 17 ноября 2020).

Дубровский Д. (2018b) Вопросы гуманитарной судебной экспертизы в январе-феврале 2018 г. Amicus Curiae. Доступно по ссылке: https://www.amicus-curiae.info/ analytics/473 (дата обращения: 17 ноября 2020).

Дубровский Д. (2019) Идеологический донос под видом научного знания. Ridl. Доступно по ссылке: https://www.ridl.io/ru/ideologicheskij-donos-pod-vidom-nauchnogoznanija/ (дата обращения: 17 ноября 2020).

Дуэль И., Злобин А., Путко А. (1993) Апрель против «Памяти». Хроника одного судебного прочесса в документах и лищах. Т. 3. М.: Пик.

Кондрашев А.А. (2017) Судебная реформа в России: проблемы реализации и варианты решений. Актуальные проблемы российского права, 2 (75): 209-218.

Россинская Е.Р., Галяшина Е.И. (2017) Судебная экспертология: история и современность (научная школа, экспертная практика, компетентностный подход). М.: МГЮА.

Секераж Т.Н., Кузнецов В. О. (2016) Комплексная судебная психолого-лингвистическая экспертиза: формы, виды, перспективы развития». Теория и практика судебной экспертизы, 4 (44): 98-107.

Соколов М, Титаев К. (2013) Провинциальная и туземная наука. Антропологический форум, 19:239-275.

Kondakov A. (2016) Teaching Queer Theory in Russia. QED: A Journal in GLBTQ Worldmaking, 3 (2): 107-118. 
Kondakov A. (2020) The Queer Epistemologies: Challenges to the modes of knowing about sexuality in Russia. In: Z. Davy, A.C. Santos, C. Bertone, R. Thoreson, \& S.E. Wieringa (eds.) The SAGE Handbook of Global Sexualities, Vol. 1. London: Sage: 82-98.

Verkhovsky A. (2016) Radical nationalists from the start of Medvedev's presidency to the war in Donbas: True till death? P. Kolstø, H. Blakkisrud (eds.) The New Russian Nationalism: Imperialism, Ethnicity and Authoritarianism, 2000-2015. Edinburg: Edinburg University Press: $75-103$. 
Dmitry Dubrovskiy

\title{
THE ACADEMIC COMMUNITY AND 'HUMANITARIAN' FORENSIC EXPERTISE ON EXTREMISM IN MODERN RUSSIA
}

\begin{abstract}
In the late 1990s and early 2000s, democratically-minded scientists built the institutional framework for forensic expertise in the humanities and contributed to setting the boundaries of freedom of speech, actively cooperating in this with law enforcement agencies. This was due to the idea of these experts about the danger of 'Russian fascism' (neo-Nazism) and about the required civic stance of a scientist. In this, democratic science sided with the state in its disputes with conservative-nationalist circles, often clashing in courts with conservative academics who defended nationalist views in the courts. As a result, at this time, the institution of special forensic examination was formed as a whole and research methods appeared, which were based on the experience of conducting such examinations. In the second half of the 2000s, the institution of expertise was intercepted by representatives of conservative science with the active participation of the state. Apparently, it was no coincidence that this coincided with the emergence of special anti-extremist legislation, which began to actively narrow the space for freedom of speech. As a result, part of the academic community not only participated in the application of anti-extremist legislation, but also contributed to its scientific legitimation. Then the parties actually changed places: if in the first period representatives of the democratic community were on the side of the accusation, now in the new conditions they are on the side of the defense against representatives of conservative science who actively support the position of the state. Thus, the article focuses on this interception of the institution of special forensic expertise, initially created in cooperation between civil society, the academic community ('provincial science') and the state, and handing it over to political opponents in 'native science'.
\end{abstract}

Key words: special humanitarian expertise, freedom of speech, counterextremism, academic rights and freedoms

DOI: $10.17323 / 727-0634-2020-18-4-721-736$

\section{References}

Bourdieu P. (2005) Pole nauki [Scientific Field]. In: Shmatko N. A. (ed.) Sotsiologiya pod voprosom. Sotsial'nye nauki v poststrukturalistskoy perspektive [Sociology in Question. Social Sciences from a Post-structural Perspective]. Moscow: Praksis: 15-56.

Dmitry Dubrovskiy - Cand. Sci. (Hist.), Associate Professor, Faculty of Social Sciences, School of Politics and Governance, Public Policy Chair, NRU-HSE, Moscow; Center for Independent Social Research, St. Petersburg; Lecturer, Free University, Moscow, Russian Federation. Email: dmitry.dubrovsky@gmail.com 
Dubrovskiy D. (2019) Ideologicheskiy donos pod vidom nauchnogo znaniya [Ideological Delation under the Guise of Scientific Knowledge]. Ridl. Available at: https://www.ridl. io/ru/ideologicheskij-donos-pod-vidom-nauchnogo-znanija/ (accessed 22 October 2020).

Dubrovskiy D. (2018a) Voprosy gumanitarnoy sudebnoy ekspertizy v yanvare-fevrale 2018 g. [Humanitarian Forensic Issues in January-February 2018]. Amicus Curiae. Available at: https://www.amicus-curiae.info/analytics/473 (accessed 22 October 2020).

Dubrovskiy D. (2018b) Spetsial'naya ekspertiza v noyabre-dekabre 2018 g. [Special Forensic Expertise in 2018]. Amicus Curiae. Available at: https://www.amicus-curiae.info/ analytics/674 (accessed 22 October 2020).

Dujel' I., Zlobin A., Putko A. (1993) 'Aprel" protiv 'Pamyati'. Khronika odnogo sudebnogo protsessa $v$ dokumentakh i litsakh ['April' vs 'Memory'. One Trial in Documents and Persons]. Vol. 3. Moscow: Pik.

Kondakov A. (2016) Teaching Queer Theory in Russia. QED: A Journal in GLBTQ Worldmaking, 3 (2): 107-118.

Kondakov A. (2020) The Queer Epistemologies: Challenges to the Modes of Knowing about Sexuality in Russia. In: Z. Davy, A. C. Santos, C. Bertone, R. Thoreson, S. E. Wieringa (eds.) The SAGE Handbook of Global Sexualities, Vol. 1. London: Sage: 82-98.

Kondrashev A. A. (2017) Sudebnaya reforma v Rossii: problemy realizatsii i varianty resheniy [Judicial Reform in Russia: Implementation Problems and Solutions]. Aktual'nye problemy rossiyskogo prava [Actual issues of Russian Law], 75 (2):209-218.

Rossinskaja E. R., Galjashina E.I. (2017) Sudebnaya ekspertologiya: istoriya i sovremennost' (nauchnaya shkola, ekspertnaya praktika, kompetentnostnyy podkhod) [Forensic Expertise: History and Contemporaneity (Academic Schools, Expert Practice and Competences)]. Moscow: MGJuA.

Sekerazh T. N., Kuznecov V.O. (2016) Kompleksnaya sudebnaya psikhologo-lingvisticheskaya ekspertiza: formy, vidy, perspektivy razvitiya [Complex Forensic Psychological and Linguistic Expertise: Forms, Types, Perspectives of the Decelopment]. Teoriya i praktika sudebnoy ekspertizy [Theory and Practice of the Forensic Expertise], 44 (4):98-107.

Sokolov M, Titaev K. (2013) Provintsial'naya i tuzemnaya nauka ['Provincial' and 'Native' Science]. Antropologicheskiy forum [Anthropological Forum], (19):239-275.

Verkhovsky A. (2016) Radical Nationalists from the Start of Medvedev's Presidency to the War in Donbas: True till Death? In: P. Kolstø, H. Blakkisrud (eds.) The New Russian Nationalism: Imperialism, Ethnicity and Authoritarianism, 2000-2015. Edinburg: Edinburg University Press: 75-103.

Vinnikov A. Ja. (2011) Evolyutsiya antifashistskogo dvizheniya v Rossii: ot sovetskogo antifashizma k intellektual'nomu i gumanitarnomu antifashizmu [The Evolution of the Anti-fascist Movement in Russia: From Soviet Anti-fascism to Intellectual and Humanitarian Anti-fascism]. Antropologicheskiy forum [Anthropological Forum], (14):310-320. 